IRA-International Journal of Education \& Multidisciplinary Studies

ISSN 2455-2526; Vol.04, Issue 03 (2016)

Pg. no. 373-380

Institute of Research Advances

http://research-advances.org/index.php/IJEMS

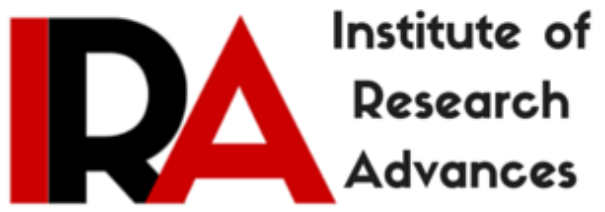

\title{
A Critical Study of Values, Self-concept and Creativity among under Graduate Students from Rural Colleges
}

\author{
${ }^{1}$ Priyanka Dafare and ${ }^{2}$ Dr. R. G. Bhende \\ ${ }^{1,2}$ Kasturba College of Education, Borgaon (Meghe), Wardha-442001, India.
}

Type of Review: Peer Reviewed

DOI: http://dx.doi.org/10.21013/jems.v4.n3.p3

\section{How to cite this paper:}

Dafare, P., \& Bhende, R. (2016). A Critical Study of Values, Self-concept and Creativity among under Graduate Students from Rural Colleges. IRA International Journal of Education and Multidisciplinary Studies (ISSN 24552526), 4(3), 373-380. doi:http://dx.doi.org/10.21013/jems.v4.n3.p3

(C) Institute of Research Advances

\section{(cc) EY-NC}

This work is licensed under a Creative Commons Attribution-Non Commercial 4.0 International License subject to proper citation to the publication source of the work.

Disclaimer: The scholarly papers as reviewed and published by the Institute of Research Advances (IRA) are the views and opinions of their respective authors and are not the views or opinions of the IRA. The IRA disclaims of any harm or loss caused due to the published content to any party. 


\begin{abstract}
Objective- The main objective of the study is to find out the values,self-concept and creativity amongUnder Graduate Students from Rural Colleges. This study will focus on comparison between the female student and male student about the values, self-concepts as per its dimensions and creativity.

Methodology- this research was done on the basis of Descriptive method. The investigator preferred normative survey for study.

Tools- the tools used for study was questionnaire PVQ by Dr Mrs. G.P. Sherry and Late prof. R.R. Verma, SCQ by R. K. Sarswat.TCW by, Dr. Baquer Mehndi .

Finding- Female students are higher than male student about Religious values.There is significance difference between male and female students about Hedonistic value, Power value and Family Prestige Value.There is no significance difference between male and female students about Aesthetic Values, Social Values, Democratic Values, Knowledge Values, Economical Values and Health Values.Female M.Ed. students are higher in self-concept in comparisons with male student. Male students are stronger than female students about physical self-concept. It is also found that Social self-concept among female is poor than male students. When compare for the Temperamental selfconcept, Educational self-concept and Moral self-concept study shows that there is no significance difference in male and female students. While in case of intelligence self-concept female student are found to be more active and stronger.Female students are more creative than male students.
\end{abstract}

\title{
Introduction
}

Education is an important from various points of views. Its field of activity is so wide that all activities and experiences are embraced in its sphere of work. Essentially it is a process of development, a development at the latent inherent capacities of a child to the fullest extent. It sublimates the animal basic instincts in a child to socially useful activities, habits of thinking and behaving. It inculcates in a child higher moral and social ideals together with spiritual values, so that he is able to form a strong character useful to his own self and the society of which he is an integral part. It cultures the student promoting social and refined patterns of behaviour. Last but not the least education infuses in the student a spirit of dynamic citizenship, international understanding and wellbeing of humanity.

\section{"To rebuild and maintain the nation's research universities, academies and industry must work together."}

Being at the apex of the educational pyramid, higher education has a key role in the education system. The NPE visualizes higher education provides to be more dynamic and of high qualities because higher education provides people an opportunity to reflect on the critical social, economic, cultural and spiritual issues facing humanity. It seeks to achieve excellence and self-development in all fields. Higher education is the back bone of the modern society. It has the power to transform human beings into human resources. Along with primary and secondary Education higher education is also on instrument to build future generation. In India majority of higher education institutions are urban centric. But majority of India still lives in village and so the topic of rural education in India is of utmost importance.

University Education Commission (1948-49) opines regarding rural universities- "Course of wisdom in creating the type of education opportunity which are appropriate to Indian rural life and to give a quality and range to that life which is now a reality". Since India lives in her villages all efforts should be made for the development of rural areas, through better system of education facilities for the rural people. New universities should be established in rural areas in order to meet the requirements of the rural people. The aim of these rural colleges and universities should be to provide general education to the boys and girls of the rural areas and to bring about the development of their individual interest, aptitude and innate potentialities. 
Rural Development in Indian is one of the most important factors for the development of India. Ultimately its responsibility comes on education. Education for rural should be of quality. It aims at making rural students civilized human beings conscious of moral and social responsibilities which lead to all round development of students. And this already development of students are depends on many factors, among these factors following three factors are most prominent, like value, self-concept and creativity.

\section{Values:-}

Values are attributes that spring from the sublimity of soul. They are sentiments of like love that involves mind, feelings, and will which are strong, deep and enduring. They are like truth, reflection of reality that is not obstructed by any kind of prejudice. They are like beauty, perfection in themselves in every sense of the term. They are like justice, the moral constituents of state that confer on everyone what is due to him/her. Values in short shape the personality of on individual. They enhance the finer side of our potential. Values are concepts that conserve life, that comfort life. That promote life and protect life. They foster peace, order, dignity, beauty, grace and delight. Values in one word are the divine side of human being. The term value in the present study means a pattern of preferences or generalized attitudes with real independent existence indicating the desirability of behaviour in terms of social aesthetical and psychological needs. According to Sherry and Verma (1980) "Value is a concept of desirable ends, goals, ideas or mode of actions which make human behaviour selective."

\section{Self-Concept:-}

Self-concept generally refers to the totality of a complex, organized and dynamic system of learned beliefs, attitudes and opinions that each person holds to be true about his or her personal existence. There is a greater deal of research which shows that the self-concept is, perhaps the basis for all motivated behaviour. It is the self-concept that gives rise to possible selves, and it is possible selves that create the motivation for behaviour.Self-concept does not appear to be instinctive; it is a social product developed though experience; it possesses relatively boundless potential for development and actualization. Because of previous experiences and present perception individuals may perceive themselves in ways different from the ways others see them.Self-concept influences how people act. Action in turn change self-concept. As children accumulate experiences, some aspects of their old self-concept are strengthened whereas others fall away and new ones take their place.

\section{Creativity:-}

Creativity can reflect in almost all human activities. A teacher teaching with some new approach, a cook cooking some new types of dish are all creators and their energies are manifested try different ways and styles. Creativity requires newness. It requires something unique, something's better, something's new association or addition to the old form, some new imagination. To create some things mechanically is not creativity because it has no newness or originality. Creativity always moves toward perfection. It makes our life more comfortable, richer and beautiful. It has been argued that by fostering pupil's creativity in the classroom, they will be helped to identify and establish a framework for their. The principal goal of education is to create men who are capable of doing new things, and not just repeating what other generation have done-men who are creators, inventors and discovers.

In this way, all these three factors have prominent place for developing all-round, civilized student. Self-concept refers to the totality of a complex, organized and dynamic system of learned beliefs, attitudes and opinions that each person hold to be true about his or her personal existence. A positive self-concept can be developed through behave objectively in knowledge oneself, and have a positive and rational thinking. It is believed that the development of student's self-concept depends on the focus of educators in classroom practice.

Cooley (1902)defined the self as "that which is designated in common speech by the pronouns of the first person singular, I ,ME,MY,MINE,MYSELF”. Lecky (1945) identified the self- 
concept as the nucleus of personality.Sarbin (1952) noted that behaviour is organised around cognitive structures. One such important structure is the self. For Sullivan the self-arises out of social interaction. Every students have deference in their self-concept. R.Arumugrajan noted that there is significant difference between male and female higher secondary students in there academic selfimage. In conclusion of her research Anuradha Mani stated that the various dimensions of family environment and academic Self-concept contributed to the prediction of Achievement. It is found by Srivastav,N. that there is relationship of aggression with self-concept and academic, non-academic perform. Study done by Sarswat, R. find out that the boy' self-concept was positively and significantly related to Social adjustment while the girl's self-concept was positively and significantly related to home, social, emotional, school as well as total adjustment. Manav,R.N. noted in his study that self-concept variables was found to be significantly related to the students achievement. Joshi, Asha, (1992) studied the Classroom morale in relation to locus of control, creativity and parentalencouragement of pupils in Hindi- medium and English- medium schools. Study done by Indira dhull, Suman find out that Values of school students are positively correlated to gender and socioeconomic states. Kishor, G.A. noted in his study that creativity was found to be significantly related to the students personality correlates. Kulshreshtha, R. (1983) studied thatValue orientations, Interests and Attitudes are as Correlates of self-concept among male \& female Adolescents. All these research found by various researcher state that there is different aspect of self-concept, values and creativity are influenced by home, school, social and other factors and it is closely related to academic achievement, personality factors. Hence present study focus on study about values, self-concept and creativity among master students of education.

\section{Objective of the study:-}

To observe the values,self-concept and creativity among under graduate students from rural colleges.

To compare the values, self-concept and creativity of male and female under graduate students from rural colleges.

\section{Hypothesis:-}

The main hypothesis of present study is that, there issignificant difference about values, self-concept and creativity among under graduate students from rural colleges as per dimensions.

\section{Methodology}

To achieve the above cited objective of the present study NORMATIVE SURVEY METHOD has been used under the descriptive research. After reviewing the characteristic of the different method of educational research, the investigator decided to use survey method for present study.

\section{Population}

The population of the study is the rural college going student of art science and commerce faculty, studying in Wardha district of Maharashtra.

\section{Sample}

The sample of the present study was limited to 60 students (30 male students and 30 female students) from the above mention population selected on the basis of simple random sampling procedure.

\section{Research tool}

PERSONAL VALU OUESTIONAIRE (PVQ developed by Dr (Mrs.) G.P. Sherry and Late prof. R.R. Vermawhich contain ten values viz - religious, social, economical, educational, power, hedonistic, knowledge, health, family prestige and aesthetic.SELF CONCEPT QUESTIONNAIRE (SCQ) developed by Dr. Raj kumarSaraswat, which contain 48 items with six separate dimensions of self-concept viz,- physical, Social, Intellectual, Moral, Educational and Temperamental. THINKING CREATIVITY BY WORDS (TCW) developed by , Dr.BaquerMehndiwhich contain 4 
parts viz- What will happen, if , Novel Uses of Things, Similarities ,Making Things more interesting and useful.

\section{Data analysis and interpretation}

The collected data was analysed by using descriptive $\&$ inferential statistics mean, standard deviation ' $t$ ' test to find out significance difference.

Difference between the male and female students about values

\begin{tabular}{|c|c|c|c|c|c|c|}
\hline Variables & $\begin{array}{c}\text { Sub- } \\
\text { sample }\end{array}$ & Numbers & Mean & $\begin{array}{l}\text { Standers } \\
\text { deviation }\end{array}$ & $\begin{array}{c}\text { 't' } \\
\text { value }\end{array}$ & $\begin{array}{c}\text { Significance } \\
\text { level }\end{array}$ \\
\hline \multirow{2}{*}{ Religious Values } & Male & 30 & 10.35 & 3.25 & \multirow{2}{*}{2.78} & \multirow{2}{*}{$S(0.05)$} \\
\hline & Female & 30 & 13.47 & 5.26 & & \\
\hline \multirow[t]{2}{*}{ Social Values } & Male & 30 & 12.01 & 4.79 & \multirow{2}{*}{1.17} & \multirow{2}{*}{ N.S. (0.05) } \\
\hline & Female & 30 & 11.03 & 4.32 & & \\
\hline \multirow{2}{*}{ Democratic values } & Male & 30 & 11.82 & 4.46 & \multirow{2}{*}{0.8} & \multirow[b]{2}{*}{ N. S. $(0.05)$} \\
\hline & Female & 30 & 11.02 & 3.23 & & \\
\hline \multirow{2}{*}{ Aesthetic Values } & Male & 30 & 12.36 & 2.87 & \multirow{2}{*}{1.37} & \multirow{2}{*}{ N. S. (0.05) } \\
\hline & Female & 30 & 13.79 & 4.97 & & \\
\hline \multirow{2}{*}{$\begin{array}{l}\text { Economical } \\
\text { Values }\end{array}$} & Male & 30 & 12.76 & 6.16 & \multirow{2}{*}{1.53} & \multirow{2}{*}{ N. S. (0.05) } \\
\hline & Female & 30 & 11.15 & 5.75 & & \\
\hline \multirow{2}{*}{ Knowledge Values } & Male & 30 & 12.74 & 5.31 & \multirow{2}{*}{1.32} & \multirow{2}{*}{ N.S. (0.05) } \\
\hline & Female & 30 & 15.78 & 5.00 & & \\
\hline \multirow{2}{*}{ Hedonistic Values } & Male & 30 & 13.09 & 4.55 & \multirow{2}{*}{2.32} & \multirow{2}{*}{$S(0.05)$} \\
\hline & Female & 30 & 10.07 & 5.54 & & \\
\hline \multirow[t]{2}{*}{ Power Values } & Male & 30 & 12.58 & 6.02 & \multirow[t]{2}{*}{2.02} & \multirow[t]{2}{*}{ S (0.05) } \\
\hline & Female & 30 & 9.4 & 6.21 & & \\
\hline \multirow{2}{*}{$\begin{array}{l}\text { Family Prestige } \\
\text { Values }\end{array}$} & Male & 30 & 10.02 & 4.17 & \multirow[t]{2}{*}{2.88} & \multirow[t]{2}{*}{$\mathrm{S}(0.05)$} \\
\hline & Female & 30 & 13.54 & 5.26 & & \\
\hline \multirow[t]{2}{*}{ Health Values } & Male & 30 & 12.16 & 5.23 & \multirow[t]{2}{*}{1.35} & \multirow[t]{2}{*}{ S.N. (0.05) } \\
\hline & Female & 30 & 10.48 & 5.28 & & \\
\hline
\end{tabular}

\section{Interpretation}

The analysis of the score of male and female rural college going student shows that the mean score of female students are higher than male student about Religious values. The obtained ' $t$ ' value (2.78) is significant at 0.05 level. This result indicates there is significance difference between the male and female. Same results are also obtained with Hedonistic value, Power value and Family Prestige Value i.e. all ' $\mathrm{t}$ ' values $(2.32,2.02$ and 2.88) is significant at the 0.05 level and result indicate there is significance difference between male and female students. The score mean about Social, Democratic, Economical,Knowledge and Health Values are higher among male than female but ' $t$ ' value (initially $1.17,0.08,1.53$ and 1.35 ) are not significant at 0.05 level as well as 0.01 level. The score mean for Aesthetic Values among female is higher than male and ' $t$ ' value 1.37 is not significant on both level(0.05 and 0.01). 
Difference between the male and female students about self-concept and its Dimensions

\begin{tabular}{|c|c|c|c|c|c|c|}
\hline Variables & $\begin{array}{c}\text { Sub- } \\
\text { sample }\end{array}$ & Numbers & Mean & $\begin{array}{l}\text { Standers } \\
\text { deviation }\end{array}$ & $\begin{array}{c}\text { 't' } \\
\text { value }\end{array}$ & $\begin{array}{c}\text { Significance } \\
\text { level }\end{array}$ \\
\hline \multirow{2}{*}{$\begin{array}{l}\text { Physical } \\
\text { self-concept }\end{array}$} & Male & 30 & 32.06 & 3.335 & \multirow{2}{*}{2.555} & \multirow{2}{*}{$S(0.05)$} \\
\hline & Female & 30 & 29.86 & 3.335 & & \\
\hline \multirow{2}{*}{$\begin{array}{l}\text { Social } \\
\text { self-concept }\end{array}$} & Male & 30 & 34.66 & 4.378 & \multirow{2}{*}{2.858} & \multirow{2}{*}{$S(0.05)$} \\
\hline & Female & 30 & 31.43 & 4.378 & & \\
\hline \multirow{2}{*}{$\begin{array}{l}\text { Temperamental } \\
\text { self-concept }\end{array}$} & Male & 30 & 30.23 & 3.73 & \multirow{2}{*}{1.35} & \multirow{2}{*}{ N. S (0.05) } \\
\hline & Female & 30 & 31.53 & 3.728 & & \\
\hline \multirow{2}{*}{$\begin{array}{l}\text { Educational self- } \\
\text { concept }\end{array}$} & Male & 30 & 30.63 & 4.15 & \multirow{2}{*}{1.41} & \multirow{2}{*}{ N. S (0.05) } \\
\hline & Female & 30 & 31.06 & 3.82 & & \\
\hline \multirow{2}{*}{$\begin{array}{l}\text { Moral } \\
\text { self-concept }\end{array}$} & Male & 30 & 31.83 & 3.335 & \multirow{2}{*}{1.07} & \multirow{2}{*}{ N. S (0.05) } \\
\hline & Female & 30 & 32.66 & 2.569 & & \\
\hline \multirow{2}{*}{$\begin{array}{l}\text { Intellectual self- } \\
\text { concept }\end{array}$} & Male & 30 & 25.9 & 4.05 & \multirow[b]{2}{*}{7.536} & \multirow{2}{*}{$S(0.05)$} \\
\hline & Female & 30 & 36.2 & 3.438 & & \\
\hline \multirow{2}{*}{$\begin{array}{l}\text { Total } \\
\text { self-concept }\end{array}$} & Male & 30 & 184.5 & 7.72 & \multirow{2}{*}{2.726} & \multirow{2}{*}{$S(0.05)$} \\
\hline & Female & 30 & 192.16 & 7.67 & & \\
\hline
\end{tabular}

\section{Interpretation}

The analysis of the score of male and female rural college going student shows that the mean score of male students are higher than female student about physical self-concept. The obtained ' $t$ ' value (2.555) is significant at 0.05 level. This result indicates there is significance difference between the male and female. Same results are also obtained with social self-concept i.e. ' $t$ ' value (2.858) is significant at the 0.05 level and result indicate there is significance difference between male and female students in social self-concept. The score mean about temperamental, Educational and Moral self-concept are higher among female than male but ' $t$ ' value (initially $1.35,1.41,1.07$ ) are not significant at 0.05 level as well as 0.01 level. The score mean for intellectual self-concept among female is higher than male and ' $t$ ' value 7.536 is significant on both level(0.05 and 0.01$)$. The score for total self-concept among female students is higher than male students. ' $t$ ' value (2.726) is also significance at both level $(0.05$ and 0.01).the data analysis shows that there is significant difference between male and female about self-concept and its dimensions. Thus all hypothesis became significant.

Difference between the male and female students about Creativity

\begin{tabular}{|l|c|c|c|c|c|c|}
\hline \multicolumn{1}{|c|}{ Variables } & $\begin{array}{c}\text { Sub- } \\
\text { sample }\end{array}$ & Numbers & Mean & $\begin{array}{c}\text { Standers } \\
\text { deviation }\end{array}$ & $\begin{array}{c}\text { 't' } \\
\text { value }\end{array}$ & $\begin{array}{c}\text { Significance } \\
\text { level }\end{array}$ \\
\hline \multirow{2}{*}{ Creativity } & Male & 30 & 27.53 & 10.89 & 2.98 & \multirow{2}{*}{$\mathrm{S}(0.05)$} \\
\cline { 2 - 7 } & Female & 30 & 35.97 & 11.08 & 2.98 & \\
\hline
\end{tabular}

\section{Interpretation}

The analysis of the score of male and female rural college going student shows that the mean score of female students are higher than male student about Creativity. The obtained 't' value (2.98) is significant at 0.05 level.

\section{Findings}

1. Female students are higher than male student about Religious values. 
2. There is significance difference between male and female students about Hedonistic value, Power value and Family Prestige Value.

3. There is no significance difference between male and female students about Aesthetic Values, Social Values, Democratic Values, Knowledge Values, Economical Values and Health Values.

4. Female M.Ed. students are higher in self-concept in comparisons with male student.

5. Male students are stronger than female students about physical self-concept.

6. It is also found that Social self-concept among female is poor than male students.

7. When compare for the Temperamental self-concept, Educational self-concept and Moral selfconcept study shows that there is no significance difference in male and female students.

8. While in case of intelligence self-concept female student are found to be more active and stronger.

9. Female students are higher than male students about Creativity

\section{Recommendations}

- The facility should be provided to rural colleges for development of values, self-concept and creativity among the student.

- The content of curriculum should be facilitate for development of values, self-concept and creativity as well as it should be as per social need.

- The self -concept should be evaluate in order to decide their area of self-concept.Teacher should use the teaching methods like problem solving method, ring toss, storm warming etc. to develop the creative power of students.

- By developing the mental abilities like imagination power, observation power, questioning of the students it is possible to develop creativity and to build self of students. Teacher should respect to the imaginations of students.

- By providing the opportunities to solve the problem, to express themselves and constructive responses can develop the creativity.

- The involvement of parents is important for development of value, self-concept and creativity.

- To avoid the coping of ideas from others the student should provide to express their imagination and ideas.

- The student should be motivated for Study of value based literature.

- The teaching methods like Self -study and research aptitude should be include in the day to day teaching.

- In democracy the democratic values should be develop among students.

- Value based curriculum should be design and value based behaviour of student should be award.

- The self-concept of students should be evaluated by using SCQ and accordingly atmosphere should be provided of self-concept.

- For development of society social values among students have to be nurture and for this content of curriculum should be value based.

- Inspiring speeches by various subject specialist, seminar, workshops etc. should organised for students.

- Students-centred approach should be used in teaching because it allows students actively use their forms of creativity.

- It can be carried out in relation to self-concept and academic achievement

- A similar study can also be carried out to see effect of school environment, home environment on students.

- A study may be taken to explore the comparison between Arts, Sciences and Commerce students.

\section{References:-}

- Saraswat(1982) 'A correlation study of self-concept Adjustment, Value, Achievement, Social-economical situation and sex.' Buch M.B.(1974) first Survey of Research in Education

- Dr.Saraswati (1971) Self-concept Questionnaire National Psychological Corporation KanheriGhat, Agra.

- Kulshrestra (1993) 'A Study of between Self-concept value orientation among Adolescents'. Buch M.B. (1997)fifth survey of research in Education, Vol.1(1988-1992).NCERT 
- Yeshpal, "A comparative study of academic achievement, Self-concept, and Personality characteristic of the children of working and non-working women". Journal of Educational and Psychological Research, Jan. 2013.

- Mittal S. (1997) 'Self-concept and statistical achievements of the girls of working mothers and non-working mothers'. Journal of community guidance and research; 14(1), 47-52, p. 155.

- Lewe, C. M.;(1961); The self -concept Fact or Anti-fact; Psychological Bulletin, page no. 325

- Saxena, N. R. , Mishra, B. K. \&Mohanty, R. K.;(2008); Fundamental of Educational Research; Meerut: Lall Book Depot; First Edition; page No. 112

- Saxena, N. R. , Mishra, B. K. \&Mohanty, R. K.;(2008); Fundamental of Educational Research; Meerut: Lall Book Depot; First Edition; page No. 75.

- Saxena, Swaroop N.R.; ChatavediShikha; Education in Emerging Indian Society; Meerut: Lal Books.

- Sharma R. A. (2009) Parametric \& non parametric statistics in Education and psychology; Meerut: R. Lal Books

- Murdase, Vandana; (Dec. 2014) ; Value Education: A Pathway to global paradise; Edutracks vol. 14. No. 4.; Hyderabad: Neelkamal Publication.

- Nanda Renu; (2005); ERIC Project Submitted to DERPP, New Delhi: NCERT,

- Paltasingh, S. (Dec 2008); Journal of Teacher Education and Research, Vol. 3, No. 2 : Noida; page No. 54-60.

- Siddiqi, Saima; (July 2011 ISSN 0972-561X); Half-Yearly Journal Of Educational Research Indian Educational Review Vol. 49 No. 2;Delhi : NCERT; page No. 10

- Yadav, Dr. Raj Kumar; (Jan 2013); Journal of Educational \& Psychological Research; Rewari (Haryana); C.L.D.S Memorial Education society; page No. 08.

- Yahaya, Dr.Azizi Bin; (2012); Self-concept in Educational Psychology; www. Encyclopedia.self-concept.in; page No.2

- Torrance, E.P. (1977) Creativity in the classroom; Washingtm: D.C. National Education Association.

- Uppuswamy (2008) Advanced Educational Psychology; New Delhi: sterling publication.

- Vernon, P.E. (1970), creativity; England: Penguin books.

- Chaka borty A.K. (2008) Education in Emerging Indian Society; Meerut: R lal Book Depot.

- Aggarwal J.C. (2004) Teacher and Education in a developing Society; New Delhi: Vikas Publishing house. 